\title{
Analisis Efektivitas Biaya Seftriakson dan Sefotaksim pada Pasien Demam Tifoid Anak di Instalasi Rawat Inap Shofa dan Marwah PKU Karangasem Muhammadiyah Paciran Tahun 2019
}

\author{
Shofi Nurul Hidayah*1, Abdul Hakim ${ }^{1}$, Ach. Syahrir ${ }^{1}$, Wirda Anggraini ${ }^{1}$ \\ ${ }^{1}$ Program Studi Farmasi, Fakultas Kedokteran dan Ilmu Kesehatan, UIN Maulana Malik Ibrahim Malang, Malang-Indonesia \\ *E-mail: shofinurulhidayah45@gmail.com
}

\begin{abstract}
Typhoid fever is an infectious disease caused by gram-negative bacteria Salmonella typhi. The treatment for typhoid fever is symptomatic therapy and antibiotic therapy. Cost-effectiveness Analysis (CEA) is one of the pharmacoeconomic approaches to find out the comparison of the effectiveness of therapeutic results and the cost of several alternative therapies used. The purpose of this study was to analyze the cost effectiveness of antibiotic use therapy in pediatric typhoid fever patients pharmaconomically using a cost effectiveness analysis approach in PKU Karangasem Muhammadiyah Paciran Inpatient Installation and to find out the most cost-effective antibiotic therapy. This research is a descriptive observational design with retrospective data collection. The data was taken from the medical records of inpatient typhoid fever in PKU Karangasem Muhammmadiyah Paciran. The parameters used are length of stay, without fever, and total direct medical costs which include drug costs, medical equipment costs, hospital fees, laboratory fees, and doctor fees. There were 29 patients who met the inclusion criteria and exclusion. The antibiotics used are Ceftriaxone and Cefotaxime. Cost-effectiveness is stated in ACER (Average Cost Effectiveness Ratio) obtained from the mean total direct medical costs divided by the average clinical outcome. The ACER value of the Ceftriaxone Rp.346.357,04 / day for length of stay and Rp.447.853,61 / day for length of without fever and Cefotaxime Rp.390,452.88 / day for the length of stay and Rp.489.655,89 / day for the length of without fever. The most cost-effective antibiotic is Ceftriaxone.
\end{abstract}

Keywords: ACER, Pharmacoeconomic, Typhoid fever

\begin{abstract}
ABSTRAK
Demam tifoid adalah suatu penyakit infeksi yang disebabkan oleh bakteri gram negatif Salmonella typhi. Pengobatan untuk demam tifoid berupa terapi simtomatik dan terapi antibiotik. Cost-effectiveness Analysis (CEA) adalah salah satu pendekatan farmakoekonomi untuk mengetahui perbandingan efektivitas hasil terapi dan biaya dari beberapa alternative terapi yang digunakan. Tujuan dari penelitian ini adalah untuk menganalisis efektivitas biaya terapi penggunaan antibiotik pada pasien demam tifoid anak secara farmakoekonomi dengan pendekatan analisis efektivitas biaya di Instalasi Rawat Inap PKU Karangasem Muhammadiyah Paciran dan untuk mengetahui terapi antibiotik yang paling cost-effective. Penelitian ini merupakan penelitian deskriptif yang bersifat observasional dengan pengambilan data secara retrospektif. Data diambil dari rekam medis pasien rawat inap demam tifoid anak di PKU Karangasem Muhammmadiyah Paciran tahun 2019. Parameter yang digunakan adalah lama rawat inap, waktu bebas demam, dan total biaya medis langsung yang meliputi biaya obat, biaya alat kesehatan, biaya rawat inap, biaya laboratorium, dan biaya dokter. Pasien yang sesuai dengan kriteria inklusi dan eksklusi berjumlah 29 pasien. Antibiotik yang digunakan adalah Seftriakson dan Sefotaksim. Efektivitas biaya dinyatakan dalam ACER (Average Cost Effectiveness Ratio) yang diperoleh dari rerata total biaya medis langsung dibagi dengan rerata outcome klinis. Nilai ACER dari antibiotik Seftriakson Rp.346.357,04/hari untuk lama rawat inap dan Rp.447.853,61/hari untuk lama waktu bebas demam, dan Sefotaksim Rp.390.452,88/hari untuk lama rawat inap dan Rp.489.655,89/hari untuk lama waktu bebas demam. Kesimpulan dari penelitian ini adalah bahwa antibiotik yang paling cost-effective yaitu Seftriakson.
\end{abstract}

Kata Kunci: ACER, Farmakoekonomi, Demam Tifoid 


\section{Pendahuluan}

Demam tifoid adalah suatu penyakit infeksi yang disebabkan oleh bakteri gram negatif Salmonella typhi [1]. Penyakit ini bisa menyerang manusia dari usia anak-anak hingga dewasa, laki-laki maupun perempuan. Gambaran klinis dari penyakit ini yaitu terjadi demam tinggi yang lebih dari 1 minggu dengan temperature diatas $39^{\circ} \mathrm{C}$ dan bisa mengalami peningkatan. Gejala demam tersebut diikuti dengan gejala penyerta lainnya, diantaranya adalah konstipasi, sakit kepala, nyeri abdomen, sakit tenggorokan, dan bisa disertai dengan bintik kemerahan pada permukaan kulit [2].

Penyakit demam tifoid merupakan penyakit menular yang bersifat endemik dan hampir terbesar di sebagian besar negara berkembang termasuk Indonesia [3]. Menurut data World Health Organization (WHO) prevalensi di seluruh dunia sebanyak 17 juta jiwa per tahun. Sedangkan di Indonesia terdapat pasien demam tifoid $0,5 \%$ per tahunnya, yang mana demam tifoid menempati urutan ke-3 dari 10 penyakit terbanyak pasien rawat inap di Rumah Sakit seluruh Indonesia [4]. Di wilayah Jawa Timur angka kejadian demam tifoid sebanyak 483 kasus [5]. Kejadian demam tifoid di Lamongan terdapat prevalensi sebesar $1,38 \%$ diagnosis dan sebesar 1,75\% diagnosis disertai dengan gejala [6].

Berdasarkan data kejadian penyakit demam tifoid yang tinggi, data kematian pun menunjukkan angka mortalitas yang tinggi. Hal tersebut ditunjukkan pada data WHO (2008), yang menjelaskan bahwa di dunia terdapat 60.000 kasus kematian setiap tahun. Dan di Indonesia terdapat 1.103 kasus kematian dari 80.850 kasus akibat demam tifoid [4]. Sedangkan di wilayah Jawa Timur terdapat $0,8 \%$ angka kematian dari 1000 kasus per bulan di rumah sakit [3]. Penderita demam tifoid banyak dijumpai pada populasi yang berusia 3-19 tahun (prevalensi 91\% kasus) [7]. Berdasarkan presentase tersebut, jelas bahwa anak-anak sangat rentan untuk mengalami demam tifoid.

Prinsip penatalaksanaan demam tifoid masih menganut trilogi penatalaksanaan yang meliputi istirahat dan perawatan, diet dan terapi penunjang (baik simptomatik maupun suporatif), serta pemberian antibiotik. Pemberian antibiotik untuk terapi demam tifoid tergantung pada sensitivitas isolat Salmonella typhi setempat. Dan berdasarkan studi pendahuluan, PKU Karangasem Muhammadiyah Paciran menggunakan terapi antibiotik untuk demam tifoid anak yaitu obat Seftriakson atau Sefotaksim.

Menurut PKB-LXII (2012) menyatakan bahwa pemberian obat sefalosporin generasi ketiga seperti seftriakson diindikasikan pada kasus-kasus yang resistensi terhadap obat kloramfenikol dan obat antibiotik untuk demam tifoid lainnya. Seftriakson cukup aman untuk diberikan pada anak dengan dosis $80 \mathrm{mg} / \mathrm{kg} / \mathrm{hari}$ selama lima hari dibandingkan dengan kloramfenikol diberikan dengan dosis 20-100 $\mathrm{mg} / \mathrm{kg} /$ hari selama seminggu, sehingga didapatkan hasil bahwa efikasi dari kedua antibiotik tidak jauh berbeda. Namun pemberian antibiotik seftriakson selama lima hari saja dapat mengurangi biaya pengobatan dan mengurangi trauma psikologis pada anak yang mejalani perawatan rumah sakit yang berkepanjangan [8].

Menurut WHO (2011), biaya yang diperlukan untuk pengobatan demam tifoid cukup tinggi. Sebuah penelitian menyatakan bahwa analisis efektivitas biaya pengobatan demam tifoid di RSUD Dr. M.M. Dunda Limboto tahun 2017, biaya pengobatan terapi antibiotik seftriakson sebesar Rp 3.650.091 dengan lama rawat inap 2,8 hari dibandingkan dengan kelompok terapi antibiotik sefotaksim dengan biaya lebih besar yaitu Rp 4.036.015 dengan lama rawat inap 3,7 hari [9].

PKU Karangasem Muhammadiyah Paciran merupakan tempat sarana berobat santri-santri pondok pesantren Karangasem dan sebagian warga Paciran. Banyaknya kasus demam tifoid anak di PKU ini dipengaruhi oleh faktor kondisi lingkungan dan aktivitas. Dan berdasarkan studi pendahuluan dalam penanganan demam tifoid anak di klinik ini menggunakan pilihan antibiotik Seftriakson dan Sefotaksim sehingga perlu dilakukan analisis farmakoekonomi berdasarkan pendekatan CEA (costeffectiveness analysis). Tujuan dari penelitian ini adalah agar diketahui terapi antibiotik yang memiliki biaya terapi yang paling efektif berdasarkan hasil terapi paling efektif dan besaran biaya yang dikeluarkan untuk terapi.

\section{Metode Penelitian}

\subsection{Jenis dan Rancangan Penelitian}

Penelitian ini adalah penelitian deskriptif yang bersifat observasional. Studi deskriptif merupakan pemaparan suatu peristiwa dilakukan sistematik fakta dan karateristik objek dan subjek yang diteliti secara tepat. Dan metode pengambilan data secara retrospektif menggunakan data sekunder. Data sekunder dalam penelitian ini adalah data yang sudah tersedia di rumah sakit yang berupa rekam medis dan biaya pengobatan serta perawatan pasien rawat inap dengan diagnosis demam tifoid yang dirawat inap di Shofa dan Marwah PKU Karangasem Muhammadiyah Paciran periode Januari 2019 sampai Desember 2019.

\subsection{Waktu dan Tempat Penelitian}

Penelitian ini dilaksanakan di PKU Karangasem Muhammadiyah Paciran. Waktu penelitian dilakukan pada bulan Februari - Juni 2020.

\subsection{Populasi dan Sampel}

Populasi pada penelitian ini adalah seluruh pasien demam tifoid anak yang di Instalasi Rawat Inap Shofa da Marwah di PKU Karangasem Muhammadiyah Paciran selama periode Januari 2019 sampai Desember 2019.

Sampel yang diambil pada penelitian kali ini adalah pasien demam tifoid anak yang menjalani rawat inap dan diberikan terapi antibiotik yang memenuhi kriteria inklusi. Kriteria inklusi pada penelitian ini adalah sebagai berikut:

a. Pasien demam tifoid anak umur 5-11 tahun. 
b. Pasien demam tifoid anak yang menggunakan terapi antibiotik Seftriakson atau Sefotaksim.

c. Pasien demam tifoid anak yang KRS karena sudah dinyatakan sembuh oleh dokter.

d. Pasien dengan data medis yang lengkap dan jelas berupa data diri pasien, durasi perawatan dirawat inap, terapi yang didapatkan, dan biaya atau harga obat yang harus dibayarkan.

\subsection{Analisis Data}

Pengolahan data pada penelitian ini menggunakan program pengolahan angka Microsoft Excel. Setalah data yang dibutuhkan sudah terhimpun, selanjutnya data tersebut diinput ke software untuk selanjutnya diolah sesuai dengan rumus ACER dan ICER. Hasil akhirnya diketahui nilai ACER dan ICER sebagai dasar penelitian efektivitas biaya terapi dari penggunaan terapi antibiotik pasien demam tifoid anak yang dirawat di PKU Karangasem Muhammadiyah Paciran. Nilai ACER dan ICER diperoleh dengan perhitungan sebagai berikut:

\section{Average Cost Effectiveness Ratio (ACER)}

$$
\text { ACER }=\frac{\text { Rata-rata biaya medis langsung (rupiah) }}{\text { Rata-rata outcome klinis (efektivitas) }}
$$

Hasil perhitungan ACER menunjukkan hasil efektif bila menunjukkan biaya (biaya medis langsung per hari) paling rendah per efektivitas yang didapat. Suatu terapi bisa dikatakan cost-effective bila memiliki biaya yang sama namun dengan efektivitas lebih tinggi atau efektivitas yang setara namun dengan biaya lebih rendah. Dan yang paling utama adalah biaya paling rendah namun efektivitasnya tinggi.

\section{Incremental Cost Effectiveness Ratio (ICER)}

ICER $=\underline{\text { Rata-rata biaya obat A (rupiah) }- \text { Rata-rata biaya obat B (rupiah) }}$ Rata- rata efektivitas obat A (\%) - Rata-rata efektivitas obat B (\%)

Jika perhitungan ICER menunjukkan hasil negatif atau semakin kecil, maka suatu alternatif obat tersebut lebih efektif dan lebih murah, sehingga pilihan terapi tersebut merupakan pilihan yang terbaik.

\section{Hasil dan Pembahasan}

Penelitian ini menggunakan sampel berupa data rekam medis pasien demam tifoid anak yang dirawat inap Shofa dan Marwah di Klinik PKU Karangasem Muhammadiyah Paciran periode Januari - Desember 2019 yang diberikan terapi antibiotik tunggal. Jumlah sampel yang memenuhi kriteria inklusi sebanyak 29 pasien. Sampel yang telah didapat kemudian digolongkan berdasarkan antibiotik yang digunakan yaitu antibiotik Seftriakson dan Sefotaksim.

Berdasarkan hasil penelitian dapat diketahui jenis kelamin pasien, terapi antibiotik, lama rawat inap, waktu bebas demam, biaya langsung yang terdiri dari biaya obat, biaya laboratorium, biaya dokter, biaya rawat inap, dan alat kesehatan. Data yang diperoleh digunakan untuk menentukan terapi antibiotik yang paling baik dengan analisis farmakoekonomi secara cost-effectiveness analysis.

\subsection{Karakteristik Pasien Berdasarkan Jenis Kelamin}

Berdasarkan jenis kelamin, pasien dengan jenis kelamin laki-laki berjumlah lebih banyak daripada pasien perempuan. Hal ini dipengaruhi oleh aktivitas dan faktor hygiene. Pengaruh aktivitas bahwa pasien laki-laki lebih rentan mengalami demam tifoid dibandingkan anak perempuan. Kondisi ini disebabkan aktivitas bermain anak laki-laki diluar rumah lebih tinggi dibandingkan dengan anak perempuan sehingga akan meningkatkan resiko terjadinya infeksi.

Hasil ini sesuai dengan penelitian yang dilakukan oleh Sari Ajeng (2016) yang menunjukkan bahwa demam tifoid anak di RSUD X periode 2016 banyak terjadi pada pasien laki-laki dengan persentase $60 \%$ (24 pasien) dibandingkan pasien perempuan dengan presentase 40\% (16 pasien) [10]. Namun, perbedaan jenis kelamin tersebut tidak ada pengaruh terhadap kerentanan seseorang terinfeksi bakteri penyebab penyakit demam tifoid, karena faktor yang mempengaruhi demam tifoid adalah kondisi lingkungan hidup dan kualitas makanan yang dikonsumsi seseorang terutama dalam hal kebersihannya [11].

\subsection{Terapi Antibiotik yang Digunakan}

Terdapat dua macam terapi antibiotik yang digunakan yaitu antibiotik jenis Seftriakson i.v dan Sefotaksim i.v. Seftriakson dan Sefotaksim adalah antibiotik golongan sefalosporin generasi III yang mempunyai khasiat bakterisidal dan bekerja dengan menghambat sistesis dinding sel bakteri dengan cara berikatan dengan satu atau lebih ikatan proteinpenisilin (penicillin-binding proteins). Hasilnya akan memberikan efek antimikroba dengan mengganggu sintesis peptidoglikan (komponen struktural utama dari dinding sel bakteri) bakteri akhirnya melisiskan karena sel-dinding autolitik enzim berlanjut sementara perakitan dinding sel ditangkap [12].

Banyaknya pola peresepan antibiotik secara intravena pada penelitian ini berkaitan dengan kondisi pasien karena pertimbangan onset yang cepat dan bioavailibilitasnya yang lebih baik dibandingkan dengan rute per oral. Onset yang cepat dan bioavailibilitas yang baik ini akan berpengaruh pada aksi dan efek terapetik obat yang akan lebih cepat tercapai.

\subsection{Lama Rawat Inap}

Pasien demam tifoid yang menggunakan terapi antibiotik Seftriakson memiliki rata-rata lama rawat inap yang paling sedikit yaitu selama 3,53 hari. Hal ini tentunya berkaitan dengan kemampuan Seftriakson yang memiliki waktu paruh lebih lama didalam tubuh yaitu sekitar 8 jam sedangkan Sefotaksim hanya sekitar 1 jam, sehingga 
aktivitas antimikrobanya lebih lama dibanding Sefotaksim. Selain itu Seftriakson merupakan antibiotik yang memiliki efektivitas tinggi terhadap bakteri gram negatif, sehingga kemampuannya dalam menghambat sintesis dinding sel bakteri Salmonella typhi akan lebih kuat dibanding Sefotaksim serta angka resistensi Seftriakson yang lebih rendah dibandingkan Sefotaksim [13].

Hasil ini sesuai dengan penelitian yang dilakukan oleh Fithria R.F dkk (2015) yang menyatakan bahwa lama perawatan yang paling singkat terdapat pada pasien yang medapatkan terapi Seftriakson (3,45 hari), kemudian diikuti Sefotaksim (3,63 hari). Lama rawat inap dapat dipengaruhi oleh tingkat keparahan penyakit, efek samping obat, kemungkinan pasien telah mengkonsumsi obat sebelum masuk rumah sakit, mutu pelayanan kesehatan yang diberikan oleh tenaga medis termasuk peralatan medis, dan fasilitas yang disediakan [14][16].

Lama rawat inap yang cepat disebabkan karena pasien telah memenuhi anjuran untuk istirahat, pengobatan dan nutrisi yang baik sehingga akan mempercepat proses kesembuhan dan lama rawat inap, sedangkan lama rawat inap yang lama disebabkan oleh karakteristik atau tingkat keparahan penyakit yang tinggi maupun kekambuhan pasien demam tifoid [15].

\subsection{Waktu Bebas Demam}

Waktu bebas demam pada pasien demam tifoid anak yang paling cepat yaitu yang menggunakan terapi antibiotik Seftriakson. Hal ini tentunya berkaitan dengan kemampuan Seftriakson yang memiliki spektrum kerja yang sangat luas dan sangat efektif terhadap bakteri gram negatif, sehingga Seftriakson lebih cepat menunjukkan waktu bebas demam [8].

Hasil ini sesuai dengan penelitian yang dilakukan oleh Fithria R.F dkk (2015) yang menyatakan bahwa waktu bebas demam merupakan salah satu parameter keberhasilan pengobatan demam tifoid, bila suhu turun maka pengobatannya berhasil dan antibiotik yang memberikan waktu bebas demam paling cepat adalah Seftriakson $(14,73$ jam), kemudian diikuti Sefotaksim (18,96 jam). Adapun beberapa faktor yang dapat mempengaruhi outcome klinis seperti lama hilangnya gejala demam yaitu tingkat keparahan penyakit, status imun pasien yang berbeda setiap individunya, adanya pemberian terapi simtomatik yang digunakan untuk menghilangkan gejala penyakit demam tifoid yang timbul, dan pemberian terapi suporatif yang digunakan untuk mengembalikan rasa nyaman dan kesehatan pasien secara optimal [16].

\subsection{Perbandingan Efektivitas Penggunaan Terapi Antibiotik}

Pasien demam tifoid anak yang menggunakan antibiotik Seftriakson memiliki efektivitas yang lebih tinggi dibandingkan antibiotik Sefotaksim. Hal ini berkaitan dengan penggunaan antibiotik Seftriakson pada pasien demam tifoid yang dapat menurunkan suhu badan penderita dalam waktu singkat dibanding antibiotik lain sehingga lebih efektif untuk dipakai. Selain itu tidak ada laporan mengenai resistensi Seftriakson dalam mengobati demam tifoid [17]. Selain itu, Seftriakson mempunyai sifat menguntungkan yaitu dapat merusak struktur bakteri tanpa mengganggu sel tubuh manusia, memiliki spektrum luas, dan resistensinya terhadap bakteri masih terbatas [18]. Berdasarkan hal tersebut, Seftriakson dianggap sebagai antibiotik yang efektif dan poten untuk mengobati penyakit demam tifoid dalam jangka waktu yang pendek.

Hasil ini sesuai dengan pendapat Sidabutar [8] yang menyatakan bahwa suatu antibiotik dikatakan efektif bila pasien yang menggunakannya menjalani rawat inap tidak lebih dari 5 hari. Sedangkan waktu bebas demam, menurut Keputusan Menteri Kesehatan tahun 2006, dikatakan efektif apabila dapat menghasilkan waktu bebas demam $\leq 5$ hari. Suhu tubuh normal pada anak berkisar antara $36,5-37,2^{\circ} \mathrm{C}$ [19].

\subsection{Biaya Medis Langsung Pasien Demam Tifoid Anak}

Biaya pengobatan langsung yang paling tinggi adalah biaya pengobatan untuk pasien pengguna antibiotik Sefotaksim yaitu sebesar Rp. 1.503.243,60. Sedangkan total biaya pengobatan langsung yang paling rendah adalah pasien yang menggunakan terapi antibiotik Seftriakson yaitu sebesar Rp.1.222.640,36.

Biaya tindakan medis adalah biaya yang dibayarkan oleh setiap pasien untuk ruang perawatan dan jasa penanganan medis yang dilakukan oleh dokter, apoteker, dan perawat selama dirawat diruangan tersebut. Biaya tindakan medis tertinggi adalah biaya tindakan medis yang dibayarkan oleh pasien demam tifoid anak pengguna antibiotik Sefotaksim, sedangkan yang paling rendah adalah biaya tindakan medis yang harus dibayar oleh pasien pengguna antibiotik Seftriakson.

Biaya laboratorium adalah biaya yang dibayarkan untuk pemeriksaan laboratorium. Pemeriksaan laboratorium ini bertujuan untuk penegakan diagnosis dan pemantauan kondisi paparan mikroorganisme penginfeksi yang memicu terjadinya demam tifoid. Biaya pemeriksaan laboratorium terendah adalah biaya pemeriksaan yang dilakukan oleh pasien pengguna antibiotik Seftriakson dan yang tertinggi adalah biaya pemeriksaan laboratorium pasien pengguna antibiotik Sefotaksim. Hal ini dikarenakan pasien pengguna antibiotik Sefotaksim lebih dominan melakukan status pembayaran secara umum.

Biaya obat atau biaya farmasi adalah nominal yang dibayarkan untuk tanggungan yang berasal dari instalasi farmasi. Tanggungan yang berasal dari instalasi farmasi meliputi obat (antibiotik dan obat-obat untuk penangganan gelaja penyerta demam tifoid) dan alat kesehatan. Status pembayaran hanya berpengaruh pada ketentuan obat yang bisa digunakan oleh status pembayaran tertentu. Biaya farmasi tertinggi adalah biaya yang dibayarkan oleh pasien pengguna antibiotik Seftriakon, dan yang terendah adalah pasien yang menggunakan antibiotik Sefotaksim. 


\subsection{Analisis Efektivitas Biaya}

Analisis efektivitas biaya dilakukan dengan metode perhitungan Average cost-effectiveness ratio (ACER). Nilai Average Cost-effectivenes Ratio (ACER) atau rasio rerata efektivitas biaya dari suatu pilihan beberapa alternatif terapi yang memiliki tujuan sama adalah rasio dengan nilai terendah [20]. Berdasarkan hasil perhitungan ACER, dapat diketahui bahwa nilai ACER yang paling rendah adalah rasio rerata efektivitas biaya dari terapi antibiotik Seftriakson yaitu Rp.346.357,04/hari untuk lama rawat inap dan Rp. 447.853,61/hari untuk waktu bebas demam. Pilihan alternative terapi yang lebih cost-effective adalah alternative terapi dengan nilai ACER yang lebih rendah daripada yang lain [21]. Hal ini menunjukkan bahwa Seftriakson merupakan pilihan terapi antibiotik yang lebih cost-effective dibandingkan pilihan antibiotik lain yang digunakan untuk terapi demam tifoid untuk pasien rawat inap demam tifoid yang di rawat inap PKU Karangasem Muhammadiyah Paciran. Perlu ditekankan kembali bahwa analisis farmakoekonomi secara Cost-Effectiveness Analysis (CEA) bukan untuk mengetahui pengurangan biaya melainkan pada hal optimasi biaya.

Posisi perbandingan hubungan efektivitas-biaya antibiotik Seftriakson berada di kolom $\mathrm{G}$ atau kolom dominan. Hal ini berarti pilihan terapi antibiotik menggunakan Seftriakson lebih direkomendasikan untuk dipilih sebagai pilihan terapi antibiotik untuk pasien demam tifoid anak di PKU Karangasem Muhammadiyah Paciran. Sedangkan posisi perbandingan hubungan efektivitas-biaya antibiotik Sefotaksim berada di kolom C yang tergolong kolom didominasi. Kolom didominasi adalah lawan dari kolom dominan yang berarti ketika ada suatu perbandingan terapi, maka otomatis yang digunakan adalah perbandingan yang berada di kolom dominan. Karena pilihan alternatif terapi antibiotik Seftriakson ketika dibandingkan dengan antibiotik Sefotaksim yang terletak di kolom dominan (G), maka antibiotik Seftriakson lebih direkomendasikan untuk dipilih sebagai pilihan terapi. Hasil ini sesuai dengan jumlah pasien demam tifoid anak di PKU Karangasem Muhammadiyah Paciran yang menggunakan terapi antibiotik Seftriakson lebih banyak daripada antibiotik Sefotaksim.

Tabel 1

Karakteristik Pasien Berdasarkan Jenis Kelamin

\begin{tabular}{c|c|c}
\hline Jenis Kelamin & Jumlah Pasien & Persentase (\%) \\
\hline Laki-laki & 17 & 58 \\
\hline Perempuan & 12 & 42 \\
\hline Total & $\mathbf{2 9}$ & $\mathbf{1 0 0}$ \\
\hline
\end{tabular}

Tabel 2

Jumlah Pasien Berdasarkan Terapi Antibiotik

\begin{tabular}{c|c|c|c}
\hline Terapi Antibiotik & Bentuk Sediaan & Jumlah Pasien & Persentase \\
\hline Seftriakson & IV & 15 & $52 \%$ \\
\hline Sefotaksim & IV & 14 & $48 \%$ \\
\hline \multicolumn{2}{c|}{ Total } & $\mathbf{2 9}$ & $\mathbf{1 0 0 \%}$ \\
\hline
\end{tabular}

Tabel 3

Lama Rawat Inap Pasien Demam Tifoid

\begin{tabular}{|c|c|c|}
\hline Bentuk Sediaan & Lama Rawat Inap (Hari) & Jumlah Pasien \\
\hline \multirow{3}{*}{ Seftriakson } & 3 & 8 \\
\hline & 4 & 6 \\
\hline & 5 & 1 \\
\hline Rata-rata & \multicolumn{2}{|c|}{ 3,53 Hari } \\
\hline \multirow{4}{*}{ Sefotaksim } & 3 & 6 \\
\hline & 4 & 5 \\
\hline & 5 & 2 \\
\hline & 6 & 1 \\
\hline Rata-rata & \multicolumn{2}{|c|}{ 3,85 Hari } \\
\hline & & 29 \\
\hline
\end{tabular}


Tabel 4

Lama Rawat Inap Pasien Demam Tifoid

\begin{tabular}{|c|c|c|c|}
\hline Antibiotik & Lama Waktu Bebas Demam (Hari) & $\begin{array}{l}\text { Jumlah } \\
\text { Pasien }\end{array}$ & Persentase \\
\hline \multirow{5}{*}{ Seftriakson } & 2 & 7 & $46,6 \%$ \\
\hline & 3 & 5 & $33,4 \%$ \\
\hline & 4 & 3 & $20 \%$ \\
\hline & 5 & 0 & $0 \%$ \\
\hline & Total & 15 & $100 \%$ \\
\hline Rata-rata & \multicolumn{3}{|c|}{ 2,73 Hari } \\
\hline \multirow{6}{*}{ Sefotaksim } & 2 & 3 & $21,2 \%$ \\
\hline & 3 & 8 & $57,2 \%$ \\
\hline & 4 & 2 & $14,4 \%$ \\
\hline & 5 & 1 & $7,2 \%$ \\
\hline & 6 & 0 & $0 \%$ \\
\hline & Total & 14 & $100 \%$ \\
\hline Rata-rata & \multicolumn{3}{|c|}{ 3,07 Hari } \\
\hline
\end{tabular}

Tabel 5

Perbandingan Efektivitas Terapi Antibiotik pada Pasien Demam Tifoid Anak

\begin{tabular}{c|c|c}
\hline Antibiotik & Rata-Rata Lama Rawat Inap (Hari) & Rata-rata Waktu Bebas Demam (Hari) \\
\hline Seftriakson & 3,53 & 2,73 \\
\hline Sefotaksim & 3,85 & 3,07 \\
\hline
\end{tabular}

Tabel 6

Data Biaya Medis Langsung

\begin{tabular}{l|c|c|c|c|c}
\hline Antibiotik & $\begin{array}{c}\text { Rata-rata } \\
\text { Biaya Obat \& } \\
\text { Alat } \\
\text { Kesehatan }\end{array}$ & $\begin{array}{c}\text { Rata-rata } \\
\text { Biaya } \\
\text { Perawatan \& } \\
\text { Rawat Inap }\end{array}$ & $\begin{array}{c}\text { Rata-rata } \\
\text { Biaya Lab }\end{array}$ & $\begin{array}{c}\text { Rata-rata } \\
\text { Biaya Dokter }\end{array}$ & $\begin{array}{c}\text { Rata-rata } \\
\text { Total Biaya } \\
\text { Medis Langsung }\end{array}$ \\
\hline Seftriakson & Rp. $371.073,70$ & Rp. $457.233,33$ & Rp. 286.000,00 & Rp. 108.333,33 & Rp. 1.222.640,36 \\
\hline Sefotaksim & Rp. 365.386,47 & Rp. $704.107,14$ & Rp. 301.785,71 & Rp. 131.964,28 & Rp. 1.503.243,60 \\
\hline
\end{tabular}

Tabel 7

Perhitungan ACER pada Pasien Demam Tifoid Anak

\begin{tabular}{|c|c|c|c|c|c|}
\hline \multirow[b]{2}{*}{$\begin{array}{c}\text { Jenis } \\
\text { Antibiotik }\end{array}$} & \multirow{2}{*}{$\begin{array}{c}\text { Total Biaya Medis } \\
\text { Langsung }\end{array}$} & \multicolumn{2}{|c|}{ Efektivitas (Hari) } & \multicolumn{2}{|c|}{ Nilai ACER } \\
\hline & & $\begin{array}{c}\text { Lama } \\
\text { Rawat } \\
\text { Inap }\end{array}$ & $\begin{array}{c}\text { Waktu } \\
\text { Bebas } \\
\text { Demam }\end{array}$ & Lama Rawat Inap & Waktu Bebas Demam \\
\hline Seftriakson & Rp. 1.222.640,36 & 3,53 & 2,73 & Rp.346.357,04 & Rp.447.853,61 \\
\hline Sefotaksim & Rp. 1.503.243,60 & 3,85 & 3,07 & Rp.390.452,88 & Rp.489.655,89 \\
\hline
\end{tabular}

Tabel 8

Perbandingan Hubungan Efektivitas-Biaya antar Terapi

\begin{tabular}{c|c|c|c}
\hline Efektivitas-Biaya & Biaya Lebih Rendah & Biaya Sama & Biaya Lebih Tinggi \\
\hline Efektivitas Lebih Rendah & A & B & Sefotaksim \\
\hline Efektivitas Sama & D & E & F \\
\hline Efektivitas Lebih Tinggi & $\begin{array}{c}\text { G } \\
\text { Seftriakson }\end{array}$ & H & I \\
\hline
\end{tabular}




\section{Kesimpulan}

Antibiotik Seftriakson memiliki nilai ACER Rp.346.357,04/hari untuk lama rawat inap dan Rp.447.853,61/hari untuk waktu bebas demam. Dan antibiotik Sefotaksim memiliki nilai ACER sebesar Rp.390.452,88/hari untuk lama rawat inap dan Rp.489.655,89/hari untuk waktu bebas demam. Antibiotik yang paling cost-effective adalah antibiotik yang memiliki nilai ACER paling rendah yaitu antibiotik Seftriakson.

\section{Ucapan Terima Kasih}

Ucapan terima kasih kepada dr. Abdul Latif selaku kepala klinik yang telah mendukung dan memfasilitasi penulis dalam penggalian data.

\section{Kelaikan Etik}

Penelitian ini telah mendapatkan persetujuan laik etik dari komisi etik RSI UNISMA dengan nomor kelaikan etik No. 12/II/2020/KEPK.RSIUNISMA

\section{Daftar Pustaka}

[1] WHO. 2011. Guidelines for the Management of Typhoid Fever. Diakses 15 mei 2019.

[2] Cucha, B.A. 2009. Essensial antibiotik edis 7. Jakarta: Departemen Kedokteran EGC.

[3] Depkes RI. 2008b. Riset Kesehatan Indonesia 2006. Jakarta: Departemen Kesehatan RI.

[4] Depkes RI. 2011. Riset Kesehatan Dasar, Badan Penelitian dan Pengembangan Kesehatan. Jakarta: Departemen Kesehatan RI.

[5] Dinkes Prov. Jatim. 2012. Profil Kesehatan Provinsi Jawa Timur Tahun 2012. (Online). www.depkes.go.id.

[6] Riset Kesehatan Dasar. 2007. Badan Penelitian dan Pengembangan Kesehatan. Jakarta: Departemen Kesehatan Republik Indonesia.

[7] Nelwan R.H.H. 2012. Tata Laksana Terkini Demam Tifoid, Continuing Medical Education, CKD. 39: 2467-250.

[8] Sidabutar S, dan Hindra LS. 2010. Pilihan Terapi Empiris Demam Tifoid pada Anak: Kloramfenikol atau SEftriakson? Sari Pediatrik. Vol.11.

[9] Sutriyati Teti T. 2017. Cost-Effectiveness Analysis Terapi Antibiotik Seftriakson dan Sefotaksim pada Pasien Tifoid di RSUD Dr. M.M Dunda Limboto. Jurnal Entropi. Vol. 12. No.1.
[10] Sari, Ajeng Permana. 2017. Analisis Efektivitas Biaya Penggunaan Antibiotik pada Anak Penderita Demam Tifoid di RSUD X 2016. Skripsi. Surakarta: Universitas Muhammadiyah Surakarta.

[11] Novita, Yulinda. 2009. Prevalensi Demam Tifoid Berdasarkan Jenis Kelamin pada Pasien Rawat Jalan di Rumah Sakit UIN Syarif Hidayatullah dari Bulan JUli 2008 sampai Juli 2009. Skripsi. Jakarta: Fakultas Kedokteran dan Ilmu Kesehatan Universitas Islam Negeri Syarif Hidayatullah Jakarta.

[12] Katzung, B.G. 2012. Farmakologi Dasar dan Klinik Edisi 6. Jakarta: EGC.

[13] Rizka Gina H, Esy Nuasy, Ressi Susanti. 2016. Analisis Efektivitas Seftriakson dan Sefotaksim pada Pasien Rawat Inap Demam Tifoid Anak di RSUD Sultan Syarif Mohammad Alkadrie Kota Pontianak. Jurnal Kesehatan. 3:84-93.

[14] Puspitarini, dkk. 2009. Analisis Average Length of Stay (AvLOS) Pasien Rawat Inap pada Kasus Typhoid Fever di Rumah Sakit Umum Daerah Sragen Periode Tri Wulan IV Tahun 2008. Jurnal Kesehatan. 3:84-93.

[15] Oktafiani Eka. 2017. Analisis Efektivitas Biaya Penggunaan Injeksi Seftriakson dan Sefotaksim pada Pasien Demam Tifoid di Instalasi Rawat Inap Rumah Sakit Umum Daerah Ambarawa Tahun 2016. Skripsi. Surakarta: Farkultas Farmasi. Universitas Setia Budi Surakarta

[16] Fithria Fillah Risha, Kiki Damayanti, dan Risma Putri Fauziah. 2015. Perbedaan Efektivitas Antibiotik pada Terapi Demam Tifoid di Puskesmas Bancak Kabupaten Semarang Tahun 2014. Prosiding Seminar Nasional Peluang Herbal Sebagai Alternatif Medicine. FKUI.

[17] Hammad, O., Hifnawy, T., Omran, D., Anwar, M., Girgis, N. 2011. Ceftriakson versus kloramfenikol for Treatment of Acute Typhoid Fever. Life Science Journal 8: 100-105.

[18] Musnelina Lili, dkk. 2004. Analisis Efektivitas Biaya Pengobatan Demam Tifoid Anak Menggunakan Kloramfenikol dan Seftriakson di Rumah Sakit Fatmawati Jakarta Tahun 2001-2002. Jurnal Maraka Kesehatan. Vol. 8. No. 2: 59-64.

[19] Kaneshiro, N.K., and Zieve, D., 2010, Fever.Universityo of Wasington. Dalam: http://www.nlm.nih.gov/medlineplus/ency/article/000980.htm . (Dikutip 29 September 2012).

[20] DiPiro J, et al. 2011. Pharmacotherapy: a Pathophysiologic Approach Sixth Edition. New York: The McGraw-Hill Companies.

[21] Kemenkes RI. 2013. Buku Pedoman Farmakoekonomi. Jakarta: Kementrian Kesehatan RI. 